\title{
Human and Citizenship Rights Education by Media
}

\author{
Amir Biparva $^{1} \&$ Seyed Ghasem Zamani ${ }^{2}$ \\ ${ }^{1} \mathrm{PhD}$ student of public international law, Imam Reza international University, Mashhad, Iran \\ ${ }^{2}$ Faculty board member of Allameh Tabatabaee University, Tehran, Iran \\ Correspondence: Seyed Ghasem Zamani, Faculty board member of Allameh Tabatabaee University, Tehran, Iran. \\ E-mail: drghzamani@gmail.com
}

Received: April 27, 2016

doi:10.5539/mas.v10n9p101
Accepted: May 19, 2016

Online Published: June 7, 2016

\begin{abstract}
Development of human rights and citizenship rights is based on publication of its concepts among the people in global society. This publication of concepts and introduction of the people from different nations to human rights are done through education. Media with their role in transfer of information and knowledge have educational function. Media with their educational function ensured education right as one of the human rights while informing the public thoughts with their own rights and increasing their demands through human rights and citizenship rights education. Human rights and citizenship rights education activate the people of society in normalization of the related rules and this media education which is directly and indirectly related to obligation of states to right of education binds the states to respond to increased demands of human rights and citizenship rights and take action regarding development of the human and citizenship rights in national and international level. Human rights and citizenship rights have exclusive capability which leads to increased awareness of states with human and citizenship rights and increased demands of states and international society considering high number of media addresses and diversity of their content in presentation of materials about human and citizenship rights in education for all society levels and increased demand leads states and international society to develop norms of the human and citizenship rights through legislation, codification and enactment of the conventions on human rights and this process leads to development of human and citizenship rights at local and global levels.
\end{abstract}

Keywords: human rights, citizenship rights, media, education, development

\section{Introduction}

Education is the main basis of human growth and ensures different dimensions of human life. Education promotes human thought and his development; therefore, education should be regarded as a right for human which leads to evolution of human.

Education leads to publication of knowledge and information and enjoyment of information by the human and normalization and increase of human skill and their evolution and all of these factors are caused by the educational right of the people. Education in different ages for people as formal educational plans or higher educational plan or informal plans by the governments, international organizations and natural persons and legal entities aims at human evolution and growth. For education, multiple functions should be considered and it should not be only limited to transfer of knowledge. New education is oriented. Education fulfills social needs of new societies while promoting the mind of person (Ghari Seyed Fatemi, 2010, p. 305). Considering that education is a social necessity so that social life of contemporary human requires education in different subjects so that it should not be regarded only as a right which human beings can enjoy but it should be regarded as an inevitable social necessity. On the one hand, people have freedom of choosing it which means freedom of extensive choice which people enjoy in the field of education and its extent based on requirements. On the other hand, education is a protective right and the state shall provide the people with educational equipment and it should be mentioned that the states are obliged to education and the states should provide the people with educational equipment at all levels.

Educational right should be searched in binding international documents in which the rules are part of customary international law and binding international documents to which the states are obliged including the Universal Declaration of Human Rights and the International Covenant on Civil and Political Rights. Article 26 of the 
Universal Declaration of Human Rights has recognized the public education for the human beings and stated that the aim of education is to develop personality of human and respect for his/her rights and freedoms. International Covenant on Civil and Political Rights has recognized educational right as one of the binding rights which the states are obliged to present to the humans. One of the most important dimensions of education which is of special importance and has been emphasized by the international society is human rights education. As mentioned in the previous line, it has been stated in article 26 of the Universal Declaration of Human Rights that education should aim at full growth of human personality and reinforcement of respect for human rights and fundamental rights. Understanding, toleration and friendship among all nations, racial and religious groups should be promoted and activities of the United Nations Organization should be accelerated to protect peace. Provisions of the said article which are among the binding rules of the customary international law state that the aim of education is to respect for human rights. Therefore, considering the aim which can be inferred from article 26 of the declaration, education can be regarded as means of ensuring human rights by enforcing it and indirect means of developing human rights and citizenship rights. The importance of human rights education is that the United Nations' General Assembly called 1994-2005 period as human rights education decade through a resolution.

In the present era, education through states is not performed based on educational plans but other institutions should be directly involved in education process beside governmental education and higher education and private universities. Human rights education mentions an important issue that is link between recognition and actions which means recognition to action and familiarity with human rights in case it results in promotion and support of this will be useless (Amir Arjomand, 1996, p. 166). To realize this interaction between recognition and action, it should be said that education should not be limited to academic classic education fields but education scope is very extensive and there are many opportunities and tools for human rights and citizenship rights education.

Education has progressed and changed in the present era which is information and communication era and information and communication technologies were highly developed so that media have main role in transfer of news and information in routine human life. Identification of instances and manifestations of human rights in all dimensions and observance, respect for, ensuring and protecting it require human rights and citizenship rights to be trained to all people through which duty of different people including the state and government and different classes can be clarified. For this public education, what can be imagined should be regarded as media because in the present era, their addressees comprise large part of society in addition to technical advances of their addressees, therefore, they have extensive function in transfer of knowledge and execution of right of education. Therefore, considering this generality, this question is raised: Can the media be effective in ensuring human rights and citizenship rights at national and international levels and also in development of these rights through the function which they have in transfer of news and education? In other words, can media ensure and develop it though human rights education?

Today, media play important role in primary sociability of children and also long-term sociability of adults and this role has been extensively accepted. According to theory of functionalism, the most important function of media is transfer of culture. Media help attract people by continuing working after formal education and also starting it in the pre-school years. Media show and display the society with which the person can introduce him and can reduce feeling of estrangement and lack of root (Severin \& Tankard, 2005, p. 452). Media have very high capacity for education at all levels and the role which media play in formation of norms, values and attitudes and behaviors is regarded as education which is beyond formal education and includes all addressees of the media (Rasouli \& Zendehboodi, 2011, p. 18). By referring to the function of media in education, media should be regarded as effective means of education and media in human and citizenship rights education increase demands of nations and civil movements to demand and execute human rights in different communities while transferring information and training the addressees and executing education for ensuring human rights by increasing awareness of the nations with human rights and citizenship rights and clarifying duties of states about the said rights. This demand of rights and clarification of duties cause the states to take actions regarding development of human rights and citizenship rights rules at national and international levels. In this research, to clarify dimensions of discussion, attempt is first made to clarify human and citizenship rights education from different aspects and specify its legal position while specifying it and consider educational function of media in human and citizenship rights and its effect on framework of international law. 


\section{Section 1: Human and citizenship rights education}

\section{A. Human and citizenship rights}

Concepts of human and citizenship rightshave common fundamentals and although citizenship rights are subject to nationality and membership in a political society and human right is right of human irrespective of the political borders, it should be noted that content of citizenship right should be found in human rights. Right of political participation, right of election, right of social security and similar rights which are among the rights of citizens of a country should be included in political, civil, economic and social rights which have been accepted as human rights at global level. Therefore, considering this relation, education of these rights is a unique trend and historical trend and concept and types of educations can be studied in a unique trend.

Concepts of human rights and citizenship rights are the concepts which may have been expanded after end of the Second World War and their expansion concurrent with establishment of United Nations is one of the goals of the United Nations and education is one of the common methods of education so that human rights education is regarded as means of promotion and development of human rights and citizenship rights. The United Nations Organization made efforts to promote and support human rights since the middle century 20 in different dimensions. Codification and enactment of international declarations and conventions for identification of human rights and continual deepening of civil, political, economic, social and cultural rights, encouragement of states to enact international conventions and more importantly, strengthening of human rights culture are among the means that the United Nations Organization and other institutions with international entity take step in development of these rights. To create culture of human rights, human rights education plays determining role and educational activities are of special importance among the activities of the United Nations Organization to promote and support human rights. As mentioned in the previous lines, basis of human rights education should be found in the Universal Declaration of Human Rights and the International Covenant on Civil and Political Rights which are the most important documents of the United Nations Organization in development of human rights and the Universal Declaration of Human Rights. In the International Conference on Human Rights which was convened in 1968 in Tehran to evaluate the progresses based on development of human rights since enactment of the Universal Declaration of Human Rights, all countries were invited to apply all of their educational equipment so that the young grow and flourish in a climate full of respect for human dignity and equality of the human rights. At the same year, the general assembly of the United Nations Organization asked its members to include the principles announced in the Universal Declaration of Human Rights and other universal documents related to human rights in its educational system (Amir Arjmand, 1996, p. 162). UNESCO held the international congress on human rights education in Vienna in 1978 and held the second international congress for human rights education in the presence of the governmental and nongovernmental specialists in Malta who codified and defined a guideline for human rights education at global, regional and national levels and defined a framework for training information and documents of human rights (Nnesco, 1993, p. 5). In 1993, the action plan of UNESCO was enacted in Montreal Congress in which human rights were considered extensively and human rights education was regarded as cause of peace and coexistence of nations (Amir Arjmand, 1996, p. 9). The declaration and action plan of Vienna are the important documents, particularly Vienna-Declaration-of-human-rights so that it includes learning of tolerance, patience and participation for all people in social life (Amir Arjmand, 1996, p. 171). Human rights education is so important for the global community that the United Nations' General Assembly announced 1995-2004 period as human rights education decade through a resolution (Note 1) and asked states to apply all of their equipment forhuman rights education.

Human rights education is of high importance and has important role in promotion and support of human rights. Human rights education causes our awareness with human rights (mahaparta, 2012, p. 26). Changing trend of human and citizenship rights education which was referred in this research confirms importance of human rights education. Therefore, it is important to clarify concept of this education to give a definition of human rights education by giving a logical definition. Human rights education can be defined as set of the efforts to train, publish and inform to create a global culture by transferring knowledge, skills and form behaviors for increasing respect for human rights and fundamental rights (Ansari, 2010, p. 13). Human rights education means training and education which constitute global culture of human rights. That education should not be only regarded as knowledge transfer but mean execution, support and development of human rights (UNESCO, 2012, p. 2). Human rights education follows a series of goals which generally should include the following cases:

- Strengthening respect for human rights and fundamental rights.

- Growth and evolution of human personality and feeling of dignity.

- Promoting toleration, understanding and tolerance and gender equality and friendship among all nations , 
native people and racial, national, tribal and religious groups.

- Enabling people to actively participate in a free community.

- Progressing and reinforcing activities of the United Nations Organization for keeping peace (Ansari, 2010, p. 17).

The above goals indicate that Human rights education is effective in executing, ensuring and developing the related rights; therefore, effect of education should be regarded as extensive considering its goals.

Human rights education encompasses broad scope including knowledge and skill and mechanisms for enforcement of human rights in life and development of human rights values and support and promotion of human rights. 12 and13 ibid.

Types of human rights education

Human rights education is more than presentation of information considering concept and inclusion of that. This education enables the people to analyze the surrounding world and find that human rights education is a method which improves their life and others' life and can take action for protecting human rights. To realize that human rights are observed in life of people and people participate in execution, support and development of human rights, human rights education should be performed at different levels as follows:

1. As the formal human rights educational plans which are organized by the states.

2. Formation of human rights informal educational plans which should be executed by the nongovernmental organizations.

3. As the ordinary media plans which include information and landscapes about changes in human rights changes (Zamani \& Bahramloo, 2013, p. 333).

4. In human rights education, education process by the human rights actors may be formal or informal which should be separated from each other. Formal human rights education is an education which is presented formally in educational centers such as schools and universities but informal education is an education beyond the school and university and each of them should be clarified separately.

Formal human rights education: Formal human rights education means human rights education in primary schools, high schools and universities which are run by the states. Formal human rights education is performed by the teacher or professional researcher in the field of human rights education. Human rights education starts since primary school and continues to end of the university course. Human rights education is taught by presenting concepts and conduct of the teachers in the schools and should be taught in other universities and faculties in addition to faculty of law (Amir Arjmand, p. 173).

Informal human rights education: Informal human rights education refers to any type of regular and organized educational activity which is performed out of the formal system to supply comprehensive and special samples inside the population to the adults and children (Zamani \& Bahramloo, p. 340). Informal human rights education is presented in the environments out of schools and universities by the governmental and nongovernmental institutions at different levels. The public human rights education which is one of the informal human rights education methods is such that it has no special addressee and its addressee is public and offers materials related to human rights irrespective of the place and continually. Public education can be organized or not organized but education is irregular and has high effect on the permanent trends and any person can acquire and save knowledge and skill through the daily experiences and disclosure. Traditionally, such discussions are made in coffee shops and corner of shops and information is transferred through radio and television and printing media and even comic books. Today, many people learn human rights through the ordinary online discussion groups known as news groups by subscribing with post lists or server lists or the subjects discussed in online groups (Zamani \& Bahramloo, p. 341)

Place of human rights education in international law:

Human rights education has been regarded as a part of education right and has been defined as a set of educational, promotional and informative activities and to observe and realize human rights and fundamental freedoms, evolution of human personality and respect for dignity of human, increase understanding, forgive and reach equality and friendship among the states and enable all persons to participate in affairs of society (Ansari, p. 13). Human rights education has been mentioned in many international documents including binding and non-binding documents and the states are bound tohuman rights education based on the customary international law and international conventions. The Universal Declaration of Human Rights as a valid declaration of which provisions are binding by virtue of the customary international law should be directed by virtue of the second 
paragraph of article 26 of the said education declaration so that human personality of everyone grows and respect for human rights and freedoms is strengthened. Education should facilitate cordial understanding, forgiveness and respect for unfriendly beliefs among all nations and racial and religious nations and populations and also development of activities of the United Nations Organization to keep peace. Provisions of article 26 indicate that human rights education should be one of the goals of educational rights and all educations should aim to realize human rights and respect for human dignity and keep peace. In the Covenant on Civil and Political Rights, educational right has not been stipulated which causes an express obligation for the states to human rights education by virtue of the said document. Necessity of the people's awareness with rights inserted in the Covenant on Civil and Political Rights requires human rights education.

The International Covenant on Economic, Social and Cultural Rights have bound the states to observe and promote human rights and fundamental rights. Based on article 13 of the Covenant, aims of education are full growth of human personality and his dignity and reinforcement of respect for human rights and fundamental freedoms. This expression in this binding international document should mean that aim of human rights education is considered while human rights education is the aim of all educational contents but any educational activity directly or indirectly affects human rights education to execute educational right.

The international convention declares removal of all racial discrimination forms as one of the binding and important documents related to human rights in its article : The contracting state is bound to take immediate and effective measures particularly in the field of learning, education, culture and information to prevent the prejudices resulting in institutional discrimination and to expand understanding, toleration and friendship among racial and tribal groups and nations and also publish goals and principles of the UN charter, the Universal Declaration of Human Rights about removal of all types of racial discrimination and the present convention. Education has included plans in the textbooks which promote understanding, toleration and friendship among the racial and tribal groups and nations for training and education. By virtue of the convention, the states should include the goals and principles of the UN charter and convention in their curriculum indicating that the states are obliged to human rights education through education and higher education system. UN Convention against Torture is one of the binding international documents and provisions of some rules have been accepted as international imperative rule. Principle against Torture which is as valid as the imperative rule in the international law. It has been mentioned in article 10 of the convention that the states interfere in training of personnel who execute law and the people who interfere in arrest and interrogation of people shall consider information and guidelines relating to prohibition of torture. The Convention on the Elimination of all Forms of Discrimination against Women declares that the contracting states take all necessary actions for removing discrimination and exercise of equal rights of women and men. By virtue of article 10 of the Convention on the Elimination of all cliché concepts regarding criticism of men and women at all levels and in all educational forms by encouraging mixed education and other types of education which will be effective in achieving this goal particularly by reviewing the textbooks and curricula of the schools and improving teaching forms of discrimination. In this convention, content and function of education in Elimination of all Forms of Discrimination against Women have been mentioned meaning that content of education is an effective step in elimination of gender discrimination in the curricula of schools. The United NationsConvention on the Rights of the Child is one of the binding and important documents relating to human rights which is agreed by the international community. By virtue of article 4 of the convention of the member states, all legal and executive measures will be taken for exercise of rights identified in this convention. These states will take such actions to maximize the sources in the framework of international cooperation considering economic, social and cultural rights. Article 19 of the convention has bound the states to take suitable legal, executive, social and educational measures to protect the children against all forms of physical and mental violence and assault and battery or abuse, negligence, misbehavior or exploitation. Educational measures for prevention of violence against children are an important step which provide human rights education to protect right of child and prevent violence against him.

Education of child, by virtue of the convention, refers to special cases and the states are obliged to include these cases in education of children:

Growth of child's personality, his talents and mental and physical capabilities as far as possible.

Expanding respect for human rights and fundamental rights and principles inserted in the UN's charter.

Expanding respect for child's parents, cultural identity, language and values of child, national values of the country in which he lives, the country which is his homeland and civilizations different from his civilization.

Preparing children for having responsible life in a free society with a spirit of understanding, peace, toleration, 
gender equality and friendship among all people of the national, tribal, religious groups in the native people.

Expanding respect for environment:

As mentioned above, the convention has bound the states to include rules of human rights in education so that what has been mentioned in article 29 means human rights education to the children and indicates that the states are obliged to human rights education of children (Nnesco, 2012, p. 12).

The declaration and action plan of the declaration and action plan of Vienna 1993 are of the valid international documents of human rights.

In the said document, general sense of human rights has been considered. Articles 78 to 82 of the declaration has dealt with important category of human rights education with emphasis on the fact that human rights education is an essential factor for reinforcing and access to the stable relations in societies and promoting mutual undemanding of patience and peace and has asked the states to try to eradicate illiteracy and ensure public information by developing plans and strategies of human rights education and publishing public information in the broad level and strengthen increased awareness with human rights by cooperating with the international organizations and national institutions .

Available at: Http://www.pajoohe.com/fa/index.php?Page=definition\&UID=42256

Importance of the human rights education for the international society is so high that the United Nations' General Assembly called 1994-2005 period as human rights education decade through a resolution. In this regard, the international society regarded human rights education as a unique strategy for building a global culture of human rights. To build a global culture, all states, international organizations, natural persons and legal entities work at national, regional and international levels. The international society has consensus over cooperation in human rights education to build culture and understand the human rights. Human rights education means development and understanding of common universal responsibility for recognition and enforcement of human rights in all communities. In this sense, it means cooperation for prevention of human rights violation and clashes and promotion of equality and development and execution of participation in the lawmaking (Nnesco, 2012, p. 12) in a democratic system.

Human rights education, by virtue of international documents which were mentioned above, is an international obligation for the states and the states are obliged to human rights education formally and informally at all levels. Of course, this education should not be only limited to the states but nongovernmental institutions and international organizations also can act along with the states in this field. The states are obliged to cause activity of the nongovernmental institutions and international organizations in the field of human rights education.

\section{Section 2: Function of media in human rights and citizenship rights education}

\section{A. Educational function of media}

Media have important role in structure of social system. The present era is called communication era. In other words, due to the presence and function of mass media which are growing, development of media in new forms encompass development in different societies. Media play important role in economy, culture and society. Media play important role in public awareness as information channels and communication tools affecting public thoughts and guard of civil society. Media play key role in social and cultural thoughts. They are the best means for education, advertisement and cultural affairs and play distinctive role in development of concepts of human rights. Media build public thoughts and are distinctive in building civilization (Mostafaye et al., 2013 p. 3402 ). Media are the effective tools in community. Media field as one of the social structures has very effective ability to form public culture (Navakhti Moghadam, 2009, p. 32). Media are very effective in attraction of the public thoughts and making public thoughts so that it should be said that they are the effective means for building social identity and form public thoughts (broad casting group, 2002, p. 12).

Based on the large communication plan serving human, establishment of new global order removed the internal barriers to free flow and more extensive and balanced publication of information, knowledge and thoughts. Considering this perspective, the second plan which has been predicted to serve human in this section as the large communication plan is directed to removal of barriers and gradual reduction of quality and quantity misbalances of information flow and progress of communication technologies and reinforcement of abilities to produce and spread messages. On this basis, news means assist in respect for human rights and international understanding and peacekeeping and generally clarification of global issues. For this reason, much attention is paid to social role of communicators and the responsibilities which they assume against the public thoughts to increase awareness (Motamed Nejad, 2011, pp. 208-209). 
Educational function of media is subject to publication of concrete information and presentation of correct methods about different issues. The educational function of media is so important that role of education should be regarded parallel or permanent for press, radio, television and internet because media perform duty of education by spreading information and knowledge in parallel to effort of teachers. Educational duty of media is not limited to educational course of people and when people graduate from schools and universities and enter social life, they have to use media for increasing and expanding their knowledge. While media helpteachers and professors for education in scientific fields, they follow role of permanent education along with schools, institutes and universities and even many cases.

Media as an accessible tool cause education in different fields for their addressees which have facilitated education and accelerated provision of knowledge in different scientific fields and communication of researchers in different sciences and updated knowledge. This function of media converts each of the media into a university or educational center (Motamed Nejad, 2007, p. 8).

Addressees of direct media education are generally the people who use media to acquire information intentionally but when we speak about indirect or hidden educations, the addressees sometimes are subject to media information inactively and unconsciously and are trained for special behaviors and acquiring skills, norms and values (Rezaee Bayandar, 2003, p. 131). Media can be included in category of powerful social institutions which are effective in process of acceptance of norms, social values and socialization of people. People learn, values, norms, beliefs and behaviors from others through media and institutionalize vales through process of social education and socialization in different frameworks. Communicative tools play special and strategic role in process of social identity building and management of community and socialization of people directly and indirectly (Mostafaye et al., p. 3405).

Educational function of media which is observed by transferring information and institutionalizing values and normalization leads them to take action regarding fulfillment of their educational function through publication and transfer of news, creation of development and cooperation to reinforce social identity, transfer cultural heritage.

Function of media in human rights education:

Media have key and undeniable role considering high number of addressee in publication of news and information. Media are important in transfer of information related to human rights and informing the addressees of human rights rules and informing them of human rights documents and also mentioning all problems related to human rights so that it can be said that media publicize human rights and are the most important tools which involve nations in human rights issues.

Media include presentation and transfer of information with different means. In the contemporary world, media is the most important information source about any subject including human rights. For most people, radio, television and newspapers are the only source of information. As a result, media have power in selection of subjects and events of the world which we know so that media decides what should compose news. Media refine and frame the subjects which we know. Media enter political subjects and discussions. Media cause awareness with issues of human rights (Teweldebirhan, 2011, p. 26). This awareness with the human rights issues indicates function of media in human rights education because education indicates awareness whose addressees are the public thoughts so that this is a type of educational workshop in which addressees and members should be regarded as the whole global society.

The public thoughts are formed based on these behaviors and react to it and stimulate legislators and political deciders about human rights issues and foreign relations. Support of media can lead to distinctiveness and elaboration of the human rights issues at social level. Without media support of the human rights subjects, these discussions will not be made in most legislative assemblies. Success of these issues should be subject to multilateral support of it in mass media (Navakhti Moghadam, p. 36).

Human rights education involve the addressees in results through media, which are useful for society (Nwanko, 2010, p. 31). The information collected with documentary programs and media interviews indicate that media have effect which is hard to prove. BBC produced a documentary programs in 2010 as Chocolate:the bitter truth in which the producer dealt with some subjects such as trafficking of childrenand compulsory labor of children by travelling to African countries and studying process of producing cacao in African farms and producing it in England plants. All of these issues indicate role of media as an actor in law showing effect of documentary programs on human rights education with BBC (Nwanko, 2010, p. 1). For example, there was an interview in the program relating to chocolate industry which indicates their role in conduct toward the people in cacao and chocolate lands and farmlands. Many consumers are not aware of these behaviors and the chocolate 
manufacturing plants were not informed of this procedure and then tried stop these behaviors resulting in violation of the workers' and children's rights indicating effect of the documentary programs. Belief in potential effect of documentary program is one of the components which have been actualized with these products. Therefore, media has positive effect on promotion of human rights by disclosing violations of human rights and giving human rights knowledge for the addressees of media. Information, education and amusement cause the media to produce documentary programs so that the documentary programs in human rights education are effective and have ability affecting the addressees.

By understanding and identifying role of mass media in international human rights issues, its educational effect on people, supervision on governments and cooperation of nongovernmental international organizations in scope of duties, the inherent importance of mass media is dealt with as an international actor and considering high number of addressee and effect of addressees and their attendance in social field, they have undeniable role in education of human rights and normalization.

Support of human rights by media should be regarded as its educational function. Efficiency and effectiveness of each legal system in the first instance depend on the fact that rules of the system are accepted by the subjects if the subjects regard the codified rules as reasonable, just and necessary, they will easily enforce it and even will be its sanction in case of violation. Therefore, understanding ethical and reasonable justifications which form basis of rules increases loyalty to rules and obedience to it (Navakhti Moghadam, p. 41).

For example, in a human rights educational workshop which had been held in Switzerland, when discussion was made about right to support racial discrimination in the workshop, the students took hard positions about how to struggle against racism flow and respect for dignity of humans while there was discrimination against foreigners in Switzerland which was led by the former mister of Justice, ChristopheBlocher. For this purpose, they decided to write a letter to minister of Justice which included many questions, criticisms and also included suggestions related to struggle against racism. Students sent a transcript of letter to the press and radio networks of Switzerland. So, letters of students to the minister of justice was spread in the media and the students held press conference which prevented his reelection as the minister of Justice in the next weeks. This is a clear example of effect of human rights education process on political changes (Huber, 2009, p. 1-2).

Media produce information for the public and reporters of media collect and present all information related to human rights. Media present information which is prepared by the human rights organization. Media are able to select content and they decide what they cover and what reports and subjects they should highlight and media with this decision-making has power to increase what is necessary for us to know for the human rights. Media have power to form public ethics and public thoughts (Available at: Http://www.speakupspeakout.internews.org/?q=section-2-concepts-skills-and-tools/media-journalism-and-huma n-rights).

The above facts all indicate importance of media in human rights education. But it should be noted that this subject has become more important with technological advances and role of media in the contemporary world in human rights education is more important than before. Internet and multimedia tools have created new perspective which led to loss of interest in traditional sources of knowledge such as press, radio and television and the main focus is to acquire information and instruct internet and new media. Media are able to attract many addressees and different populations due to their unique feature. Social networks are good tools for publication and training of human rights subjects. For example, Facebook of the United Nations Organization gives many facts about clashes of Syria, Darfur and Congo and other information related to human rights and humanitarian rights. Many international authorities are present in social networks which train the public about their performance (Herberg \& Steinberg, 2012, pp. 503-504).

Media promote awareness with human rights. Media inform people of their rights. Media present strategies to defend against human rights violation and strengthen human rights (Tewedebirhan, p. 29).

Media are tools for adjusting negative minds. In different reports, importance of media has been emphasized as tools for adjusting negative minds in different international organizations. In many reports, legal tools and policies about media have been referred which emphasize on duty of the administrators of these affairs for preventing racial discrimination (India and China) and strengthening racial convergence (Brazil and Venezuela ) and predicting methods of compensation for victims of racial discrimination. For example, India has compiled instructions for media to ensure that racial discriminations and other discriminations are not publicized and promoted (Ansari, p. 34).

Place of media education of human rights in international law: 
Attention to function of media in human rights education in international documents is of special importance because reflection of function of media in binding sources of international law can indicate place of media in international law. So, in the globalization era, international law indicates validity of media and their role in this field and international law can provide ground for educational function of media in ensuring and developing human and citizenship rights. Koichiro matsuura, the former secretary general of UNESCO regards realization of human rights impossible without effective public education. Many works should have been done to realize all civil, cultural, economic, political and social rights of human and achieve this case. Increased awareness of people with their rights is one of the important factors in successful realization of their rights. For this reason, education right for human rights is regarded essential and for this reason, knowledge and awareness of people with their rights are of the important factors in successful realization of their rights. Education right for human rights is regarded essential and for this reason, knowledge and awareness of people are of the conditions for powers of people. Only people are aware of their rights and try to enjoy them. Now, these rights in any form and size include right of finding good job, using suitable food products, house and therapeutic services, active participation in political affairs or taking advantage of scientific progresses and technology and only the people who are aware of their rights can use all tools and methods and support their and others' rights (UNESCO, 2010, p. 11).

Educational function of media in human rights education in international documents can be studied for ensuring human rights meaning that they require execution and supervision in the said rights and also for causing development of the mentioned rights in the normalization process in the framework of international conventions. In introduction to the Universal Declaration of Human Rights, any person and institution as member of the society should supervise on the declaration and make effort to teach human rights to promote rights and freedoms stipulated in the Universal Declaration of Human Rights (Tewedebirhan, p. 28). In different international binding documents, function of media has been referred in human rights education indicating obligation of states to provide the ground for human rights education by media directly and indirectly.

In Article 7 of the Convention on the Elimination of all Forms of Discrimination against Women, educational measures have been mentioned as one of the strategies for coping with racial discrimination. The related committee in the convention which is called the Committee on the Elimination of Racial Discrimination and supervises on actions of the states regarding the convention and based on which the states shall provide report based on Articles $7 \& 9$ of the convention to the committee has paid special attention to media in the 15 th meeting. So, the committee has declared in the general letter of recommendation no. 5 in the 15th meeting that the states should pay attention to role of governmental media in publication of news and information to fight against racial prejudices and better understand goals and principles of the documents related to human rights and role of mass media such as newspapers, radio and television in publicizing human rights and informing the people of goals and principles of human rights documents and give it to the information committee. The United NationsConvention on the Rights of the Child is accepted by the international society as an international binding document and the states are obliged to execute them. In Article 29 of that convention, education directed children to expand respect for human rights and fundamental freedom and principles inserted in the UN charter. In article 17 of the convention, function of media in education of children has been considered based on article 29. Based on article 17 of the convention, the member states emphasize on importance of functions and duties of mass media and will ensure access of children to different national and international information and facts particularly the information which causes promotion of social, spiritual and ethical welfare and physical and mental health of the child. By virtue of the first paragraph of article 18, the states considering article 29 of the convention are obliged to encourage the mass media to publish social and cultural information and materials for children. This expresses importance of human rights education for children and obligation of states to human rights education for the children which plays key role in institutionalization of culture of human rights (Ansari, p. 29).

Resolution 184/49 of the general assembly of the UN Organization which announced 1995-2004 period as human rights education decade has emphasized on function of media in human rights education so that media reinforcement has been known as an effective tool for human rights education (Ansari, p. 18). By virtue of the documents which were summarized here, function of media in human rights education has been accepted and based on the international law, media plays role in human rights education and developing and ensuring it through direct and indirect education and the statesare obliged to apply media in human rights education and provide ground for activities of media in human rights.

\section{Conclusion}

The present era which is era of information and communication technologies and new functions are created for them with new progresses of these technologies so that it is proper to name this period as information era. 
Regarding knowledge transfer and education, these technologies have special capability in education. Changes of the contemporary world which exclude the international relations from relations among the states and contemporary international law is no longer the law governing relations of states but it has been accompanied by increase of the international actors so that main focus of this law should be on support of human. Media should be regarded as an active actor which can arise at international level beyond political and geographical borders and can be regarded as an effective tool for supporting human.

Media is regarded as a tool which is effective in rapid transfer of knowledge and information and has high number of addressees who receive knowledge from media and spend very long hours in receiving facts from media. Spending time and taking high volume of information from media indicates their effect on the people so that media specify demands of people and their life and their values. Media play key role in mentioning values of society and forming them and they form values at any era. Education is no longer limited to schools and universities but media assume duty of training at different levels beyond academic environments. Media are more involved in education process than the universities and schools and their addressees are more extensive than academic gathering and their educational content is broader and more diversified. Media have increased access to knowledge and information for the addressees and lead their addressee at any level to receive knowledge irrespective of time and space limitations and they can act more effectively than other educational institutions while presenting educational content considering variety of content in terms of education and have special ability to attract addressee and affect the addressee.

Media are important considering their function in human and citizenship rights education which has been referred in the binding international documents such as the United NationsConvention on the Rights of the Childfor human development through development of human rights and citizen rights. Media, irrespective of the fact that they participate in education process and participate through their educational function to ensure education right by executing that right. They participated directlyin human rights and citizen rights education process and communicate directly with the addressees indicating execution of education right and role of media in ensuring human and citizenship rights by executing one of the human binding rights to which the states are obliged. But media are not only limited to education and execution of the states' obligation to human rights education but their educational function is also effective in development of these rights. Educational function of media leads to formation of norms and is effective in emergence of values and norms considering that it increases awareness of their addressees to the said rights and considering high number of addressees. Human and citizen rights education process leads to formation of behavioral patterns of nations and states leading to formation of norms. Human and citizen rights education increases demands of human rights of different nations at national and international levels and this increase of demands binds the states and international society to develop rules of human and citizen rights by legislating and enacting the international covenants and respecting human rights rules. These actions which the international society and states perform based on increase in demands of nations to developHuman and citizen rights indicates indirect role of media in development of human and citizen rights. Although media don't participate directly in enactment of laws and international conventions for human rights, they participate indirectly in development of human and citizen rights by increasing awareness of nations and increasing demands of the states and international society.

\section{References}

Amir, A. A. (2009, Spring and Summer). Human rights education. Legal research journal. No. 25-26.

Ansari, B. et al. (2010). Human rights education. Tehran. Majd Scientific and Cultural Assembly.

Broadcasting Study Group (2002). Direct broadcast of the satellite in 21th century, Tehran, soroush publication.

Ghari, S. F., \& Seyed, M. (2010). Human rights in the contemporary world, 2, Tehran. Shahre Danesh.

Herzberg, A. \& Steinberg, G. M. (2012). Ihl2.0: Is there role for social media in monitoring and enforcmen? Israel law review, 45(3).

Huber, A. (2015). Refelection on the role of the media for the humanrights and humanrights education, available at http://www.humanrights.ch/upload/pdf/090818_Media_HRE_Presentation_AH.pdf seen at 10/8/2015

Mahpatra, N. (2012). Role of education in promotion and protection of human rights. Odisha Review, lxix(2).

Mostafaye, F. H. P., \& Mohsen, M. (2013). The role of mass media in expanding human rights discourse. International research journal of applied and basic scienses, 4(11).

Motamed, N. K. (2007, 2011). International communication (2nd Eds). Tehran. Media Studies and Development Office. Mass media. Tehran. Allameh Tabatabaee University Publication. 
Navakhti, M. A. (2010, Spring and Summer). Functional role of mass media in expansion of human rights and establishment of Perpetual Peace. Human Rights, 1 .

Nwanko, V. C. (2011). The role of media in promoting of humanrights: An analysis of the bbc documentary, chocolate the bitter truth, master thesis, school of global studies, university of gotheberg, school of business and social sciences, rohempton university, department of social anthropology, university I tromoso Teweldebirhan, sable, the role of media in the promotion of human rights in ethoiopia, master thesis, faculty of law, university of addis ababa.

Rasouli, M. R., \& Zendeh, B. K. (2011). Media and citizen rights education. Public relations researches. No. 60.

Rezaee, B. \& Mohammad, R. (2003, Spring). Studying role of media in education of citizenship skills and civil behaviors. Research and Evaluation Journal, 33.

Severin, \& Tankard, J. W. (2005). Theories of communication. Translated by Alireza Dehghan. Tehran. University of Tehran.

Unesco (1993). Human rights teaching, International congress on education for human rights teaching, Paris, Unesco.

UNESCO (2010). Toward Knowledge-based Societies (R. S. A. Mohammad, Trans.). Tehran. Majd Scientific and Cultural Assembly.

Unesco (2012). United Nations. Andunited nations humanrights, world programe for human rights education, Geneva, United Nations.

Zamani, S. G., \& Bahramloo, M. (2013). Human rights and internet. Tehran. Khorsandi Publication.

\section{Note}

Note 1. un resolution 49/184 23 december 1994.

\section{Copyrights}

Copyright for this article is retained by the author(s), with first publication rights granted to the journal.

This is an open-access article distributed under the terms and conditions of the Creative Commons Attribution license (http://creativecommons.org/licenses/by/3.0/). 